Journal of Management

Vol. 44 No. 2, February 2018 470-500

DOI: $10.1177 / 0149206314563983$

(C) The Author(s) 2015

Reprints and permissions:

sagepub.com/journalsPermissions.nav

\title{
Large-Scale Events as Catalysts for Creating Mutual Dependence Between Social Ventures and Resource Providers
}

\author{
Peter McNamara \\ Maynooth University \\ Federica Pazzaglia \\ Karan Sonpar \\ University College Dublin
}

\begin{abstract}
We examine the resource mobilization efforts undertaken by a social venture to organize the 2003 Special Olympics World Summer Games and bring about a change in social attitudes towards the cause of learning and intellectual disabilities. In contrast to previously advanced views of social ventures as powerless actors, we find instead that they are able to leverage the visibility afforded by large-scale events to create positions of mutual dependence, which allow them to access broad support bases and assert themselves in relationships with external parties. Specifically, we find that resource mobilization involves six distinct tactics rooted in the softer forms of power, namely, attraction and inducement. The use of these soft-power tactics depends upon the social venture's goal at different moments of the relationship with its partners and the level of support available from each external party. Our elaborated theory highlights both the role and limitations of soft power in mobilizing resources and managing relationships.
\end{abstract}

Keywords: social ventures; mutual dependence; resource dependence theory; soft power

\footnotetext{
Acknowledgments: This article was accepted under the editorship of Deborah E. Rupp. The authors would like to acknowledge the comments and generous feedback provided by Anver Ben-Ner, Don Bergh, Peter Clayburn, Stewart Clegg, Ed Freeman, Jeff Harrison, Danielle Logue, Sally Maitlis, Robert Ulmer, Samir Shrivastava, and Ian J. Walsh. We would also like to acknowledge the support, insights, and time of all our interviewees and especially Paul Brown, who connected the first author with Special Olympics Ireland and provided invaluable support. A number of people have provided research assistance over the years and helped with part of the data collection, for which we are grateful. These include Lynette Britton, Carolin Grampp, Garrett Murray, Grainne Power, and John Walsh. Finally, we would like to thank the reviewers and action editor of the Journal of Management for their comments and extensive suggestions throughout the review process. An earlier version of this article received the Carlo Masini Award at the 2012 Academy of Management Conference. The order of authorship has been indicated alphabetically.
}

Corresponding author: Peter McNamara, School of Business, Maynooth University, Maynooth County Kildare, Ireland. E-mail: petermcnamara@nuim.ie 
There are indeed many barriers that still exist and people with a learning disability encounter negative attitudes every day. ... Sport and participation in Special Olympics is a tremendous way to break down barriers and to raise awareness of people with a learning disability and to bring attention to their ability rather than their disability. It is for this reason and this reason alone that the bid to bring the World Games to Ireland was initiated.

—Mary Davis, CEO, Special Olympics Ireland Organizing Committee (2000: 17)

\section{Introduction}

In July 1998, it was formally announced that Special Olympics Ireland (SOI) had won the bid to organize and hold in Ireland the 2003 World Summer Games ("the Games") for individuals with learning and intellectual disabilities. As the opening quotation highlights, SOI saw the Games as an opportunity to raise awareness of the cause of learning and intellectual disabilities and promote long-term changes in public attitudes. However, the challenges facing SOI at the outset of its bid were daunting because running the Games successfully required obtaining significant resources from a number of external sources. SOI's access to resources was further challenged by limited public awareness of what these disabilities entail and what can be perceived in society as a lack of any pressing need to remedy the problems of misinformation and unawareness. ${ }^{1}$

Entities seeking to mobilize resources for social causes frequently face the kind of challenges that confronted the SOI. While entrepreneurial activities with predominantly social objectives can be pursued by a wide variety of entities, including nonprofit organizations, for-profit corporations, and governmental organizations, this article focuses on nonprofit social ventures (e.g., the SOI). A social venture can be defined as an entity that

targets an unfortunate but stable equilibrium that causes the neglect, marginalization, or suffering of a segment of humanity; who brings to bear on this situation his or her inspiration, direct action, creativity, courage, and fortitude; and who aims for and ultimately affects the establishment of a new stable equilibrium. (R. Martin \& Osberg, 2007: 39)

Nonprofits face greater challenges than other entities when advocating for social causes, such as a limited access to talent and capital (Austin, Stevenson, \& Wei-Skillern, 2006; Di Domenico, Tracey, \& Haugh, 2009).

Recognition of the enormous challenges faced by these entities in mobilizing the resources necessary to pursue the advocacy of their chosen social causes effectively has motivated a growing body of academic literature (e.g., Austin et al., 2006; Bennett \& Sargeant, 2005; Dacin, Dacin, \& Matear, 2010; Desa \& Basu, 2013; Tilcsik \& Marquis, 2013). The studies on resource mobilization by social ventures, however, have tended to concentrate on the role of resource providers, exploring, for example, why resource providers choose to contribute to a given social cause and how their involvement is effectuated (e.g., Bennett \& Sargeant; Tilcsik $\&$ Marquis). In contrast, the role of social ventures in mobilizing resources has received little attention despite evidence that these actors can and do take proactive steps to manage their resource needs (Desa \& Basu; Di Domenico, Haugh, \& Tracey, 2010). While Di Domenico and colleagues (2009) note that interactions between social ventures and resource providers can be tension ridden and lead to conflicts due to differences in priorities and assumptions, 
there is a dearth of theory on how relationships between social ventures and external partners evolve through the course of the resource mobilization process.

The above state of the literature motivates our research question: How do social ventures mobilize external resources and how do they manage relationships with their resource providers? We attempt to generate some answers through a qualitative study of SOI's efforts to mobilize the resources needed to organize the 2003 Games. Our focus on the use of largescale events to mobilize resources is timely in light of their growing adoption by social ventures to generate support and visibility for social causes (Tilcsik \& Marquis, 2013). Our study draws on recent developments in resource dependence theory (e.g., Santos \& Eisenhardt, 2009; Villanueva, Van de Ven, \& Sapienza, 2012) and explores how social ventures mobilize support for causes despite occupying positions of relative resource disadvantage.

We make three contributions to the literature. First, we provide evidence that despite being resource needy, social ventures can create mutual dependence and successfully offer their external partners access to valued outcomes. Thus, we urge a shift away from the pervasive assumption that social ventures are largely powerless in their relationships with their resource providers. In doing so, we echo and qualify recent critiques of the view of resourceneedy organizations as "passive bystanders" (Katila, Rosenberger, \& Eisenhardt, 2008: 325; also see Di Domenico et al., 2009; Haugh, 2007). When resource mobilization is viewed through the lens of mutual dependence, a different narrative emerges that cannot be adequately explained by extant theory. This new narrative draws attention to how social ventures actively create conditions of mutual dependence with external parties through organizing large-scale events as opposed to merely positioning themselves as recipients of handouts and patronage. In our model, social ventures recognize the dynamic nature of relationships with external parties and tailor their tactics in accordance with the levels of support received and the maturity levels of the relationships in question. While recent studies suggest that "resource mobilization may be better explained by the mutual or joint dependence between two parties than by the power imbalance in the relationship" (Villanueva et al., 2012: 27; also see Desa \& Basu, 2013), they do not explain how this might be achieved. Similarly, Barringer and Harrison observe that while several studies have focused on "why interorganizational relationships are formed . . . very little research has focused on how they are managed" (2000: 396; also see Laplume, Sonpar, \& Litz, 2008). We provide one explanation of how social ventures might mobilize resources and manage their relationships with their partners.

Second, we make a contribution by drawing attention to the catalytic role that large-scale events distinctly embedded in a social venture's local community play in facilitating mutual dependence and mobilizing resources for social causes. This contribution echoes Tilcsik and Marquis's (2013) comment that large-scale events can disrupt the status quo and their concerns with how the overemphasis on globalization has reduced the attention paid to actions occurring within local communities. At the same time, we also go beyond their study by adopting a social venture-centric approach to generate insights into how large-scale events embedded in the local community allow social ventures to engage with multiple external parties, transform power relations, foster mass participation, and promote social change. Our approach highlights several tactics adopted by social ventures, such as the use of both emotion- and interest-laden appeals and the pursuit of an optimal balance between decentralization and centralized control.

Finally, we make a contribution by elaborating the role of "soft power," which is said to entail the use of attraction or inducement (Nye, 1990; Santos \& Eisenhardt, 2009) and is the 
core logic that facilitates resource mobilization. We propose an elaborated and dynamic theory of resource mobilization that identifies six distinct soft-power tactics employed by social ventures contingent upon resource providers' level of support to the social cause and the maturity of the relationship with them. This study's emphasis on soft power complements prior studies that have focused primarily on harsher forms of power, such as force and coercion. While harsher forms of power may not be viable in the context of social ventures, this study underlines the role of soft power in enabling positive social outcomes. The dynamic resource mobilization model that we propose gains salience in light of observations about prior studies offering a static and thereby limited view of the social entrepreneurship process (see Hitt, Ireland, Sirmon, \& Trahms, 2011). Our study partially addresses calls for future studies to explore "issues of resource acquisition, mobilization, and bundling in a social entrepreneurial context to gain key insights into the entrepreneurial process" (Dacin et al., 2010: 50). In effect, we advance resource dependence theory by focusing on the underexplored issue of "[which] strategies organizations will use [to acquire and mobilize resources], and how the use of these strategies will vary over time and circumstances" (Pfeffer \& Salancik, 2003: xxvi). In the process of doing so, we also highlight the constraints and limitations of soft power in mobilizing resources.

\section{Background on Resource Mobilization by Social Ventures}

A crucial, albeit challenging, activity in the process of addressing a social problem is that of acquiring the physical, financial, human, and intangible resources required to carry out the venture's mandate (Austin et al., 2006). Evidence on this activity can be found in three conversations in the literature that have largely developed independently of each other. In this section, we introduce each of them in turn, highlighting their contributions to our understanding of how social ventures acquire resources and noting areas for future elaboration.

\section{Corporate Philanthropy and Cause-Related Marketing}

Several studies have documented that corporations often get involved in supporting social causes as a way to improve their reputation and legitimacy as a socially responsible entity (Muller \& Kraussl, 2011; Peloza, 2006; Williams \& Barrett, 2000), to appeal to existing and prospective customers and employees (Creyer \& Ross, 1997; Luo, 2005; Varadarajan \& Menon, 1988), and to respond to CEOs' or founders' specific interests (J. Martin, Knopoff, \& Beckman, 1998). For volunteers and corporations alike, an esprit de corps, or feeling of loyalty, towards their communities often plays a role (Crampton \& Patten, 2008; Tilcsik \& Marquis, 2013). Tilcsik and Marquis, for example, document a marked increase in charitable contributions in areas affected by high-impact events, such as natural disasters, and argue that this occurs as these events augment the salience of the "local identity" in the eyes of corporate donors and, thus, strengthen their ties with the local community.

The involvement of resource providers generally occurs through mechanisms such as charitable donations, volunteering, and cause-related marketing (e.g., Creyer \& Ross, 1997; Lev, Petrovits, \& Radhakrishnan, 2010; Varadarajan \& Menon, 1988; Williams \& Barrett, 2000). Of these activities, charitable donations and volunteering are considered purely philanthropic in nature. Others, such as cause-related marketing, are generally driven by a 
combination of philanthropic and commercial motives (Bennett \& Sargeant, 2005; Varadarajan \& Menon). Although each party is fundamentally driven by different base motives, these cooperative arrangements provide social entities with the resources they need to create social value while also allowing their commercial counterparts to reap benefits (Tracey, Philips, \& Haugh, 2005).

\section{Bricolage and Communication}

Recently, evidence has emerged in various domains about how resource-needy organizations seek to actively manage and control their resource needs. These studies broadly fall within either of two camps. The first camp comprises research that is specifically interested in the role of bricolage as a mechanism for resource acquisition. Bricolage is defined here as "making do by applying combinations of resources already at hand" (Baker \& Nelson, 2005: 333). In these studies, it is posited that social ventures replace the resources they do not possess but need to pursue their missions by devising creative uses for "undervalued, slack, or discarded resources that are often available for free or cheaply" (Desa \& Basu, 2013: 29). However, while often ingenious, bricolage is not without limitations since not all resources can be bypassed or done away with. Additionally, resorting to bricolage often leads to ventures satisficing as opposed to maximizing (Duymedjian \& Rüling, 2010) to achieve their goals.

Researchers in the second camp evaluating how entrepreneurial organizations meet their resource needs have explored the role of language and communication in facilitating resource acquisition (e.g., Lounsbury \& Glynn, 2001; Maguire, Hardy, \& Lawrence, 2004; Martens, Jennings, \& Jennings, 2007; Zott \& Huy, 2007). These scholars document the use of language-based tactics by social ventures, such as storytelling and capitalizing on high-profile or celebrity relationships, to establish familiarity and inform prospective partners of track records and aspirations. These tactics are especially important for social ventures advocating low-profile causes since prospective partners often need and wish to be convinced of the "potential usefulness" of the cause that they support (Di Domenico et al., 2010: 697).

\section{The Role of Mutual Dependence}

The views of resource mobilization discussed above, although useful, have recently come under scrutiny because they underestimate the benefits that accrue to both resource-needy organizations and resource providers. Win-win outcomes become possible when the established ties are characterized by mutual dependence and lack of vulnerability of either party (Gulati \& Sytch, 2007; Villanueva et al., 2012). Resource-needy organizations, in particular, stand to gain by "creating a platform for joint action" (Parmigiani \& River-Santos, 2011: 1115). Examples of technology ventures collaborating with larger resource-rich partners by creating mutual dependence through patents and trade secrets (Katila et al., 2008) are a case in point. Mutually dependent relationships allow entrepreneurial ventures to tap a wider range of resources under more favorable conditions than do asymmetric relationships (Vestrum \& Rasmussen, 2013).

Tracey and colleagues ascribe the benefits of mutually dependent relationships to a rebalancing of "power relations [between a focal organization and its resource providers, which] 
are transformed because partners are seen as sources of valuable assets, knowledge and expertise, rather than recipients of patronage or charity" (2005: 327). However, while there is growing awareness of the benefits of mutually dependent relationships to resource providers, relatively little is understood about how social ventures establish, manage, and benefit from such relationships (Dacin et al., 2010; Parmigiani \& River-Santos, 2011). The arguments made by researchers who urge a focus on mutual dependence are not necessarily antagonistic to earlier studies on corporate philanthropy (e.g., Marquis, Glynn, \& Davis, 2007; Tilcsik \& Marquis, 2013), which have highlighted the vulnerability of donors and sponsors to community demands given that goodwill and reputation could affect future revenues.

The recent literature has, on the whole, urged a shift away from a corporate-centric view of collaborative relations and expressed concern with the assumption that social ventures are powerless entities characterized by one-sided dependence upon external parties. Instead, researchers have called for greater attention to the role of mutual dependence and the changing nature of power relations between social ventures and external parties. Following these developments, we pay particular attention to the role of power in its more nuanced and subtle forms (Keohane \& Nye, 1998; Santos \& Eisenhardt, 2009) as an enabler of resource mobilization efforts by social ventures, since the interaction between partners with different interests is generally shaped by power relationships (Cook \& Emerson, 1978; Di Domenico et al., 2010).

\section{Method}

This article draws on a qualitative case study of a social venture's efforts to establish and manage its relationships with various resource providers in the context of organizing a largescale event. The aim is theory elaboration, that is, to extend and refine extant understandings of resource mobilization by social ventures, rather than theory generation. Theory elaboration "contrasts pre-existing understandings with observed events in order to understand extant theory" (Greenwood \& Suddaby, 2006: 31) and uses a mixture of inductive and deductive reasoning (also see Lawrence, Malhotra, \& Morris, 2012). Qualitative research is particularly suitable for studying the research question at hand because it allows researchers to conduct in-depth investigations into poorly understood phenomena in order to provide richer understanding (e.g., Eisenhardt, 1989; Van de Ven, 2007). Additionally, a qualitative approach is appropriate for exploring socially grounded phenomena, such as the one examined in this study, which involve complex social processes and relationships and offer rich insights into how actors' social experiences are created (Eisenhardt \& Graebner, 2007; Van de Ven; Yin, 2003).

\section{Research Context}

We have chosen to study the resource mobilization efforts of the SOI, which advocated the cause of learning disabilities through organizing the 2003 Games, because several theoretical concepts of interest were "transparently observable" (Eisenhardt, 1989: 537) in this context (Yin, 2003). First, it was clear from our initial investigations that SOI would have forged several relationships with external parties in order to organize the Games successfully, since the Irish government had funded only $19 \%$ of its budget. Additionally, the SOI was 
much smaller than the organizations that had hosted similar events in the past. In 1998, the year in which the SOI won the bid, it had only eight paid staff, and its annual budget was approximately $€ 722,798$. The CEO and the chairman of the Games' organizing committee were respectively appointed only in 1999 and 2000.

Second, large events with significant community relevance can serve as powerful tools to help introduce changes in attitudes towards social causes (Glynn, 2008). This context therefore promised to be a fruitful one for our study. Third, the need for the SOI to establish relationships with individuals and organizations with frequently opposing interests offers a setting in which tensions and reconciliatory efforts are amply visible, thereby affording us a greater understanding of how social ventures manage relationships with their resource providers from the initial sign up until the delivery of the promised resource. Finally, the choice of this setting ensured that key occurrences related to our case study were well documented and a number of data sources were available to us (Maguire et al., 2004).

\section{Sources of Data}

Interviews. The primary source of data was interviews conducted with senior and middle managers on the Games' organizing committee, representatives of corporate entities, public-sector and semi-autonomous agencies, and volunteers who had been directly involved in the organization and execution of the 2003 Games. ${ }^{2}$ The first author had been involved in some earlier work on learning disabilities with one of SOI's managers, who facilitated access to several early informants. These initial informants identified additional individuals, thereby rendering the sampling both deliberate and emergent. This process continued until 29 informants had been identified: 14 SOI managers, 9 representatives of corporations, 4 senior government officials, and 2 volunteers from the community. Six informants were interviewed twice, giving a total of 35 interviews. Of these, 15 interviews were conducted in 2002 and 20 in 2003. The two waves of interviews were comparable in terms of their coverage of informants. In addition to these 35 interviews, which were taped and transcribed, 4 additional interviews were conducted: 1 with an SOI manager, 1 with a volunteer, and 2 with representatives of corporations. In these cases, detailed field notes were taken but interviews were not recorded. This was due to the informants' request not to be taped (3 interviews) and to a recording malfunction (1 interview).

Interviews were conducted at the informants' place of work and with an average duration of $45 \mathrm{~min}$. They followed a semi-structured format. Interviews with SOI's managers began with a request to talk about their roles and to describe their responsibilities. Informants were also asked to talk about the individuals, groups, or organizations with which their departments interacted and to describe how they had been identified, the opportunities and challenges these interactions presented, and how the challenges had been addressed. Interviews with representatives of corporate entities and public-sector and semi-autonomous organizations began with a request to explain how their organizations had become involved with SOI and what their respective involvements in the Games entailed. They were also asked to identify the opportunities they derived from their involvement with SOI, the issues that they faced, and how those issues were or had been dealt with. Volunteers were asked to describe their role and responsibilities and how they had decided to become involved with the Games and to explain the issues they confronted in their interactions with SOI, as well as how the issues had been handled. 
Archival data. We collected over 1,000 pages of archival records on the Special Olympics, including planning documents, presentations, brochures, and press releases that SOI had issued, along with press articles (see Table 1). Of these documents, 1,069 pages provided insights that were particularly relevant to our research question and, thus, were used in our analysis. Some of these records were available publicly, while others came directly from our informants. Newspaper articles were collected from the LexisNexis database. An initial search for articles referring to the 2003 Games, SOI, and its management (e.g., "CEO" and "chairman") produced 1,826 articles. After we excluded irrelevant and repeated articles, there were 280 articles left. This material provided background about public events and actions taken by the SOI, corporate entities, public and semi-autonomous entities, and volunteers before and during the Games. It was also used to check and corroborate the available evidence on how the social venture managed its relationships with its resource providers as revealed by our analysis of the interviews.

\section{Data Analysis}

We examined all data in order to develop a fine-grained chronological description (Yin, 2003) of the events taking place in the period from 1998, when the SOI won the bid to host the Special Olympics, to 2003, when the Games took place. Our use of multiple data sources to include interviews and archival records allowed us to acquire a rich understanding of the phenomenon under consideration (Jick, 1979). In preparing this description, we pursued both within-methods (i.e., across interviews) and between-methods (i.e., across different data sources) triangulation (Jick). The chronologically ordered data described the significant events associated with SOI's attempts to organize the Games: how they came about, when they took place, the persons involved, and what the outcomes were.

Overall, our analysis follows established techniques for theory elaboration and involves a mixture of inductive and deductive reasoning (e.g., Lawrence et al., 2012). As we progressed in our analysis, recently published literature on resource mobilization by entrepreneurial and social ventures (e.g., Desa \& Basu, 2013; Santos \& Eisenhardt, 2009) focused our attention on how attracting potential partners and managing dependencies would be key objectives for the SOI. We were thus more keenly attuned to such issues in the coding of the chronologically ordered data, although they did not constrain our analysis. The next step directly addressed the research question. The analysis was iterative and recursive in nature and involved identifying patterns across coded data in order to assign them to specific categories (Miles \& Huberman, 1994).

In order to address the first part of our research question, we examined all sources of data for comments on the types of support needed and the actions undertaken to achieve this support. Through this examination, we identified a number of tactics that the focal organization used to solicit participation. We coded these tactics and identified their target audiences and the response given in terms of acceptance, ambivalence, and rejection. For example, we found that the SOI representatives used appeals to commonly held values to identify actors potentially sympathetic to the cause and/or the event and then attempted to persuade ambivalent actors by portraying the Games as an opportunity to meet their individual interests. To address the second part of the research question, we examined the data for statements that mentioned challenges faced by the various actors involved in organizing the Games. We coded these challenges, noting the actors involved, the actions undertaken to address them, 


\section{Table 1}

\section{Data Sources}

\begin{tabular}{|c|c|c|c|}
\hline Type of data & Source & Description/volume & Uses \\
\hline \multirow[t]{4}{*}{ Interviews } & - SOI managers & $\begin{array}{l}\text { - Nine interviews in 2002; } \\
\text { nine in } 2003\end{array}$ & $\begin{array}{l}\text { - Understand the SOI's } \\
\text { objectives for the Games } \\
\text { - Understand how they identified } \\
\text { resource providers } \\
\text { - Understand how these } \\
\text { relationships evolved over time }\end{array}$ \\
\hline & - Corporate sponsors & $\begin{array}{l}\text { Five interviews in } 2002 ; \\
\text { nine in } 2003 \text {; interviews } \\
\text { were conducted with all } \\
\text { four levels of corporate } \\
\text { sponsors }\end{array}$ & $\begin{array}{l}\text { Explore why they had become } \\
\text { involved with SOI and what } \\
\text { resources and capabilities they } \\
\text { provided } \\
\text { - Comprehend the issues they } \\
\text { faced in their interactions with } \\
\text { SOI and whether and how they } \\
\text { were resolved }\end{array}$ \\
\hline & $\begin{array}{l}\text { - Public-sector } \\
\text { agencies }\end{array}$ & $\begin{array}{l}\text { - Two interviews in } 2002 \text {; } \\
\text { two in } 2003\end{array}$ & $\begin{array}{l}\text { - Understand why they had } \\
\text { become involved with SOI and } \\
\text { what resources and capabilities } \\
\text { they provided } \\
\text { - Comprehend the issues they } \\
\text { faced in their interactions with } \\
\text { SOI and whether and how they } \\
\text { were resolved } \\
\text { - Understand why they had } \\
\text { become involved with SOI }\end{array}$ \\
\hline & - Volunteers & $\begin{array}{l}\text { - One interview in 2002; } \\
\text { two in } 2003\end{array}$ & $\begin{array}{l}\text { - Comprehend the issues they } \\
\text { faced in their interactions with } \\
\text { SOI and whether and how they } \\
\text { were resolved }\end{array}$ \\
\hline \multirow[t]{3}{*}{$\begin{array}{l}\text { Company } \\
\text { documents }\end{array}$} & $\begin{array}{ll}\text { - } & \text { Planning } \\
\text { documents }\end{array}$ & $\begin{array}{l}\text { - Policy manuals issued by } \\
\text { SOI (136 pages) }\end{array}$ & $\begin{array}{l}\text { - Understand SOI's portrayal } \\
\text { of strategic and functional } \\
\text { objectives and needs }\end{array}$ \\
\hline & - Press releases & $\begin{array}{l}\text { Web site press releases } \\
\text { (248 pages) }\end{array}$ & \\
\hline & $\begin{array}{l}\text { - Presentations to } \\
\text { resource providers }\end{array}$ & $\begin{array}{l}\text { Presentations to corporate } \\
\text { sponsors, volunteers, and } \\
\text { staff (139 pages) }\end{array}$ & $\begin{array}{l}\text { - Understand SOI's portrayal of } \\
\text { its needs and objectives and } \\
\text { how it responded to the issues } \\
\text { faced in the interactions with } \\
\text { its partners }\end{array}$ \\
\hline $\begin{array}{l}\text { Other } \\
\text { documents }\end{array}$ & $\begin{array}{l}\text { - } \text { Press reports } \\
\text { - } \quad \text { Feedback surveys }\end{array}$ & $\begin{array}{l}\text { - } 280 \text { newspaper articles on } \\
\text { the Games between } 1998 \\
\text { and } 2003 \text { ( } 220 \text { pages) } \\
\text { - } \quad \text { Newspaper of the Games } \\
\text { (192 pages) } \\
\text { - Memories of the Games } \\
\text { (91 pages) } \\
\text { - SOI awareness survey ( } 25 \\
\text { pages) } \\
\text { - Volunteer experience } \\
\text { survey ( } 18 \text { pages) }\end{array}$ & $\begin{array}{l}\text { - Understand the background to } \\
\text { public events and actions taken } \\
\text { by SOI, corporate sponsors, } \\
\text { national governing bodies, and } \\
\text { volunteers before and during } \\
\text { the Games }\end{array}$ \\
\hline
\end{tabular}

Note: $\mathrm{SOI}=$ Special Olympics Ireland. 
and the outcomes of these actions. Our analysis revealed that SOI was intensely political and proactive in managing its relationships with resource providers. Their management efforts included making a series of requests for additional commitments of resources from sympathetic parties and using subtle influence tactics with sympathetic-turned-ambivalent counterparties in order to restore their initial involvement.

We took several steps in our methods to enhance the quality of our findings. First, multiple coders independently coded the data and discussed the development of the codebook. Additionally, as the second and third authors were not involved in the collection of interview data, they were able to bring outsiders' perspectives to the interpretation of the results and verify emerging insights. Second, gathering and analyzing data from a variety of sources ensured a more solid understanding of the phenomenon through data triangulation (Van de Ven, 2007). Third, a teaching case developed using part of the data (McNamara, Murray, Grampp, \& Brown, 2003) was shared with a few key informants to verify the background on the Games and to confirm the sequence of key events, a practice akin to member checks (Nag, Corley, \& Gioia, 2007). Finally, we also looked for disconfirming evidence to highlight the limitations of our theoretical model.

\section{Findings}

Our research question was, How do social ventures mobilize external resources and how do they manage relationships with their resource providers? As we analyzed our interview and archival data, we found that the SOI used the 2003 Games as a catalyst to generate involvement in the cause of learning disabilities and to eventually create mutual dependence with various external parties. We found that the SOI employed six distinct tactics rooted in softer forms of power in its interactions with resource providers. This allowed the SOI to attract early pledges for support, consolidate and strengthen relationships with resource providers, and eventually exert control. The tactics employed by the SOI were contingent upon how the relationship with its partner evolved. That is to say, whether the relationship remained supportive or, with the passage of time, became ambivalent or even adversarial. We label the soft-power tactics that were employed by the SOI as appeal, persuasion, guidance, negotiation, leverage, and cooptation. While three of these tactics - appeal, guidance, and leverage - were rooted in attraction, the other three, persuasion, negotiation, and cooptation, were anchored to inducement. We discuss each of these tactics in the next section. However, our proposed framework is dynamic, since we recognize that a supportive partner can become ambivalent or even adversarial (and vice versa) over the course of the relationship.

\section{Facilitating Involvement With the Games and the Social Cause}

The first aspect that we were interested in studying concerned how social ventures leveraged the visibility afforded by large-scale events to facilitate the involvement of external resource providers. We found that the SOI developed various appeals aimed at establishing emotional resonance between prospective resource providers and the event. Consistent with the extant literature (see Shrock, Holden, \& Reid, 2004), we define emotional resonance as the connection between the emotional lives of a target audience and the manner in which the call for action is framed and pitched to its members. One way in which the SOI went about 
establishing emotional resonance with the event was by drawing attention to the segregation that people with learning disabilities experience in their daily lives in order to demonstrate how this treatment contradicted core societal values, such as equality and respect for human dignity (see Table 2 for representative quotations). As a middle manager said, "People everywhere will understand that these people have feelings, emotions, abilities, and similarities just like the rest of us." On a similar note, in an interview with the press, a senior manager said,

We want everyone to know that our athletes are citizens of their own countries, and full and equal citizens of the world. ... If we can help to raise the consciousness of the world to that fact, we will have achieved all our goals. (Watterson, 1999: 23)

Another way in which SOI's representatives built emotional resonance with the event involved positioning the success of the Games as a collective achievement, especially through the use of references to positive emotions, such as pride. By building emotional resonance, SOI was able to inspire a sense of personal responsibility for the fates of the Games in a large number of individuals, reaching more than just those with prior firsthand exposure to learning disabilities. Multiple informants observed that while the SOI consistently identified the athletes as its core stakeholder group, it also emphasized how the Games were an inclusive event whose implications reached beyond the domain of people with learning disabilities. This was done through the use of expressions such as "common goal," "one team," "share the feeling," and "united effort" - all of which aimed to invoke a sense of shared ownership of the event:

The vision for the Games was a very simple vision. It was to host Games that the athletes would have been proud to participate in and that Ireland would be proud to host. That simply was the vision and what everybody knew as the vision for the Games. (Senior manager, SOI)

Initially, the SOI's appeals resonated mainly with individuals who had direct exposure to learning disabilities and volunteering and with those who wanted the prejudices surrounding the cause to be lifted. They also attracted the attention of the Irish government, an agency that wished to improve its track record with the cause, and of the premier sponsor who genuinely wanted to make a difference:

I think $100 \%$ of people know that Special Olympics is a really, really good cause and think it is wonderful that the Games are coming to Ireland and then we get so much positive feedback [for] the fact that [we] made this happen right. So in terms of say our strategy for the sponsorship, rather than just sticking logos on to Special Olympics, our strategy is to make sure that [our] contribution results in a better experience for everybody that is involved with Special Olympics.

The SOI also took steps to persuade ambivalent individuals and organizations to lend their support to the event. An aspect of the persuasion efforts by SOI representatives that emerged from our analysis was their framing of prospective partners' involvement in the successful organization of the Games as a means through which all parties involved would achieve valued outcomes. By justifying collaboration on the basis of a convergence of interests, the SOI was able to establish a wider base of support for the event than would have been possible 


\section{Table 2}

\section{Evidence of Tactics Used to Facilitate the Involvement of Prospective Resource} Providers

\section{Categories}

Appeal
Representative quotations

“This was about giving back to another human being. It wasn't for the bottom line. ... You were actually going to see the results of this in the quality of life of another human being." (Middle manager, SOI)

"When North Carolina did the Games, it wasn't Special Olympics North Carolina that bid for the Games, it was the Tourism Department that bid for the Games, because it was going to bring money, it was going to bring all sorts of benefits. For us, we did it because we wanted to raise more awareness, we wanted to create more opportunities for people with a learning disability." (Senior manager, SOI)

"The strap-band we used for the Games, 'Share the feeling', allowed everybody to share in a feeling of joy, excitement, pride." (Senior manager, SOI)

"The 2003 World Summer Games need your help to open a world of joy and opportunity for Special Olympics athletes all over the world. Today, time is the most precious commodity that any individual possesses." (Belfast News Letter, 2001: 56)

"We put a lot of emphasis on people-centered Games. ... We started that off by saying who were the people, it was athletes first of all and the feeling that they created amongst certain people here in Ireland and their whole attitude, and their determination, courage and strength and endurance and skill, and all those things, inspired people." (Senior manager, SOI)

"All the competitors - as well as the eventual medalists - will triumph, but the real winners at this year's Special Olympics will be sport itself, and the volunteers, supporters and members of the Irish public who get involved and "share the feeling.", (Battersby, 2003: 11)

Persuasion "[With corporate partners] we talk about things like mutual destiny, mutual success." (Middle manager, SOI)

"The organisers said that as this was the biggest event in Ireland in 2003, people would be foolish not to put their names down." (Irish News, 2002: 6)

"People are more aware that giving themselves brings an awful lot more to them than they would have thought before." (Senior manager, SOI)

"The key early on, however, was to secure a prime sponsor who would act as a catalyst to attract other corporations to sponsor the Games. This was easier said than done, according to [the CEO of the organizing committee] . . . so when we got [them] involved as the main sponsor, it gave a huge boost to the entire corporate sponsorship campaign." (Irish Times, 2003: 61)

"We would have organised the launch event [for the Volunteering Programme] in City Hall. . . . We would have had an invited audience of about 400 people including media. And we would have presented plans of the Volunteer Programme at that event in order to launch it." (Middle manager, SOI)

"We approached at official sponsorship level which was a million pounds at the time and that's a level we pitched at now, if people said no, we would say, 'We will come back at a later stage, official supplier level if you are interested'; some said yes some said no." (Middle manager, SOI)
Audience

All

All

Sponsors

Volunteers

Volunteers

Sponsors

Volunteers

Sponsors

Note: $\mathrm{SOI}=$ Special Olympics Ireland.

through moral or emotional appeals alone (see Table 2). A central aspect of SOI's persuasion consisted in emphasizing the reputational benefits that commercial partners would derive 
from their involvement with the Games, such as greater visibility for their products and services, improved employee and customer relations, and being perceived as good corporate citizens. A middle manager explained how "having given a certain amount of value or resources to the Games [would have] helped us promote the Games but it also helped [commercial partners] identify their product." Similarly, in an article in the Irish Times, SOI highlighted,

"Last year when we were pitching to would-be sponsors we identified employee relations as a prime reason to get involved, especially for those companies with employee retention issues." ... Part of [the] presentation includes a video showing corporate employees volunteering at the Games. "When employers see just how much employees get from the experience, it is a major motivational factor." (Harrision, 2001: 17)

Our analysis showed that these arguments resonated with the commercial entities that chose to get involved in the Games. Multiple informants made comments on the commercial benefits that they expected to derive in terms of portraying their organization as being attentive to the wider community's needs. These informants variously described how the decision to become involved in organizing the event allowed "a positive reinforcement of [our] brand," "a lot of benefits to staff morale," and made it possible "[for the entity] to be seen as a good corporate citizen." An organization informant described the organization's interactions with SOI using the expression "you scratch my back and I'll scratch yours." An SOI middle manager observed that "they have given X to the Games and they've spent two times $\mathrm{X}$ telling the people that. But it was done in such a way that it helped the Games as well." Noncommercial factors also played a role in persuading some partners to get involved. These included an organization's history of support for the cause as well as an alignment between the nature of the event and an organization's own concern for the well-being of the community:

The key thing for us as an organization going forward is that we are perceived to be a good community spirited organization, trustworthy and reliable ... we thought that the Special Olympics was a nice way of reflecting those values and also saying something about what [our company] stands for. (Corporate partner)

[Our company] has a long-established tradition of working with people with disabilities. This is why our support of the World Games is an ideal partnership for us. (Corporate partner)

In the case of volunteers, the SOI's main challenge was to convince those without personal histories of volunteering or firsthand exposure to these disabilities to participate. Mass participation was considered critical to ensuring the success of the event. The SOI made frequent references to the uniqueness of the event, the positive nature of the experience, and the sense of achievement that would result from volunteering one's time to the cause. One informant recalled how volunteers were told that "through their experience, they will leave the Games a little taller, a little more aware of how really special it can be when barriers are overcome."

Earlier studies on resource mobilization efforts by entrepreneurial ventures have focused on the use of discursive tactics (e.g., Martens et al., 2007; Zott \& Huy, 2007) and signaling 
tactics (Andreoni, 2006) directed at prospective resource providers. These tactics direct their appeal mainly to the logical part of the minds of their targets (Green, 2004) and do so by helping to elucidate the focal organization's identity and ability to deliver upon its underlying purpose. Our findings reveal an additional, but nevertheless important, element of resource mobilization that has been overlooked in prior studies, namely, the use of appeals directed to the moral and emotional sensibilities of the target audience. Social ventures that advocate low-profile or stigmatized causes stand to benefit especially where public involvement is concerned when they invoke positive emotions and depict the collaborative effort as an opportunity to make a meaningful difference. Our evidence that the use of references to commonly held values and emotions facilitates the attraction of external parties towards stigmatized groups and ultimately confers power to the focal organization complements prior findings on the role of prestige in inducing attraction and conferring power through affiliation (e.g., Zott \& Huy).

In summary, our findings demonstrate that social ventures advocating low-profile, stigmatized causes leverage the visibility afforded by large-scale events to attract prospective resource providers by creating alignment between the event and their values and interests. Attraction is traditionally a key element of softer forms of power (e.g., Nye, 1990, 2004). Social ventures often require a wide range of resources to pursue their mandates and tend to rely on a larger number of partners with more heterogeneous views towards the cause than do other ventures, which are often dependent upon fewer partners. Social ventures must modify their discourse according to their target audience. These arguments lead to the following propositions:

Proposition 1a: Social ventures that seek to promote changes in attitudes will tend to do so through the organization of large-scale events that provide visibility to the social problem and allow the creation of a sense of shared ownership.

Proposition 1b: Social ventures will facilitate the involvement of external parties by developing a wide array of arguments that highlight how the event is aligned with their values and interests.

Proposition 1c: Social ventures will facilitate the involvement of external parties by developing arguments that seek to establish an emotional connection between them and the event.

Proposition 1d: Social ventures will facilitate the involvement of external parties that do not respond to their emotional appeals by developing arguments that emphasize how their involvement with the event will meet their interests.

Although some prospective partners were persuaded to get involved in organizing the Games with SOI, others were not. Organizations that chose not to get involved with the Games included mainly U.S. and European multinational companies (MNCs) based in Ireland, who had been initially targeted as possible providers of tangible and intangible resources in the form of knowledge and expertise. For example, initial documents during the bidding process specified that

[commercial partners would be] drawn from the top Irish companies, and the multinational companies who are based in Ireland. Particular emphasis will be placed on the Irish/American companies based in Ireland. It is planned that the expertise of influential Irish/American business people will be used in our approach to the major companies. (Office of the Tanaiste, 1996: 17) 
SOI's attempts to attract or persuade Irish American MNCs to act as major partners in the Games were a failure despite the strong business and cultural links between the United States and Ireland. The European MNCs also proved difficult to access. Most of the companies that pledged their support to the Games were Irish companies, Irish subsidiaries of foreign companies, or public-sector organizations. Informants explained that the main reason for this failure to attract foreign participants was the event's lack of resonance with corporate entities outside the domestic context. For example, a large European company chose not to get involved because of the limited benefits from outside of Ireland that it expected to derive from the event:

It wasn't because it wasn't the right thing to do. It would have been impossible to allocate the cost of it across Europe because it was a local event happening in Ireland. The other markets wouldn't have bought into it. (Corporate partner)

A representative of a company with international operations that the SOI had approached for a potential partnership noted that its non-Irish operators were not very interested or supportive of the company's involvement with the Games. The informant explained,

A lot of the shops are in the UK and the public image of the Special Olympics is non-existent there. So therefore it was way harder for our franchisees in England to be excited about it.

This evidence contrasts with the same company's Irish-based operations:

This year we reckon we would have put the Special Olympics logo on forty million items that we had printed, whether it was bags, or cups or jars of coffee or whatever. Everybody who's interacting with us now would be aware of it. . . Companies have wanted to do business or franchisees have wanted to join us because they perceive this is the kind of company they want to be involved with. (Corporate partner)

Thus, our analysis also shows that there are limits to the potential of tactics rooted in soft power to leverage the visibility afforded by large-scale events and to develop a network of resource providers. We find that potential partners are less likely to become involved if resource mobilization efforts by social ventures fail to tap into their commercial and emotional interests. This is more likely to occur when social ventures seek to involve organizations located outside of the referent community. Accordingly, we argue that the benefits to organizations from their involvement with social initiatives are mainly embedded in a local context (see Marquis et al., 2007). Promised or anticipated positive reputation spillovers are likely to be greater in the case of community-embedded partners because geographic proximity to events facilitates stakeholders' awareness and appreciation of their involvement. Additionally, community-embedded events tap into and amplify the salience of the local identity (Tilcsik \& Marquis, 2013), something which would resonate more strongly with partners located within the referent community than with partners located outside of it. This argument leads to our second proposition:

Proposition 2: Social ventures will be more successful in facilitating the involvement of external parties who are embedded in the local community than of those who are not. 


\section{Consolidating the Relationship With Resource Providers}

The second aspect that our study focused on pertained to how social ventures managed their relationships with resource providers. Our analysis reveals that SOI engaged in two tactics to consolidate the relationships with its resource providers beyond the initial indications of support: guiding those who continued to be supportive in such a way as to set the basis for collaboration and then also negotiating with those who had threatened to withdraw from the event to ensure that they would return to being supportive or at least would remain involved in spite of reduced contributions. Table 3 provides illustrative examples of these tactics.

The first tactic involved drawing supporters' attention to the presence of multiple opportunities to contribute and allowing some decentralization of responsibility over how these contributions would be delivered, primarily as a way to sustain commitments from supportive external parties. The SOI representatives promised that every contribution, independent of its nature and its magnitude, would be recognized and make a difference. This approach allowed the SOI to access the resources it needed while simultaneously strengthening its initial arguments on the inclusive nature of the event. The SOI consolidated its relationship with supportive commercial entities by developing a tier-based structure wherein different tiers reflected the different commitment of resources that each partner was willing to make. A greater commitment of resources gave each partner the opportunity to showcase its support of the Games at prominent events. Such a structure allowed the SOI to appeal both to larger organizations, which could afford to take on more prominent roles, and to smaller ones, which could still be involved on a smaller scale by providing resources that were inexpensive or relatively easy to source. The SOI's flexible and imaginative approach, which enabled partner organizations to contribute in multiple ways, also appealed to individual members of the community who often wished to get involved as volunteers but were concerned about lacking specific skills. Many informants shared how the SOI personnel had frequently emphasized that all contributions and skills were important and welcome. A middle manager explained,

There are obviously specialised areas ... they are specialised skills that the ordinary person might or might not have ... I have heard of people who have looked at the application form and said "I don't have any of those skills." That doesn't mean we don't want them. We want everyone who is willing to give their time and their energy to this. We are not going to turn away anyone.

Several individuals responded to SOI's entreaties for specific skills as well. For example, an informant recalled, "I had a skill that I knew that they needed. I felt like I could contribute something very specific ... I had skills that could really be put to very good use" (Volunteer). On a similar note, the Irish Times captured this point in its reporting of a volunteer's views on the subject:

"I wasn't long back in Ireland after living away for years, when I saw the ad looking for people. Before that, I knew nothing about the Special Olympics," he says. "I used to do some riding for the disabled in England, and I thought I could offer the skills I had. It's the first time the Games will be in Ireland, and I wanted to be part of it. I tell everyone I come in contact with that I've volunteered, and I try to get them interested, too." (Boland, 2002: 11) 
Table 3

\section{Evidence of Tactics Used to Consolidate the Relationship With Resource Providers}

Categories

Guidance

Negotiation

\begin{abstract}
Representative quotations
“"A mature lady asked me last week if she was too old to volunteer: the message needs to go out that everyone has something to offer, and that we are not only looking for people with sports-related skills,' Maguire says. 'Somebody making the tea is doing a very important job, and older people have time to offer that working people don't have."' (Boland, 2002: 11)

"Some [ties with sponsors] are straightforward commercial in that they see us the
\end{abstract}

Audience

Volunteers same as any other client, some are part commercial in that they need to have us as a commercial client because they can't give it to us for nothing but they are giving us a significant discount and then there is a very small group that is giving us the facilities for nothing - so it is a mixture." (Middle manager, SOI).

"[The Games] got the benefit of the expertise and skills that various people had ... depending on their roles." (Sponsor)

"There was enough ingenuity at a level to say 'We can solve this, here's the parameters, we're not doing anything wrong,' and you had to have the confidence to let them go and solve it. And we couldn't and we shouldn't get involved." (Senior manager, SOI)

"If someone wants to be a volunteer they fill in an application form ... on the application form people give their names and addresses and phone numbers etc. They can indicate what skills they have.... What we are in the process of doing now is interviewing all those people ... and then after that training. ... There are three different types of training, there is generic training, about dealing with people from foreign delegations and most importantly dealing with people with a learning disability ... and also a little bit about world Games and what Special Olympics is actually about.... And then there is venue-specific training where they have a walk-through of what venue they will be at." (Middle manager, SOI)

"[Volunteers] can express a preference of what functional area or volunteer opportunity they want to be involved in. ... The preference is based on what area is preferable for them to work in and on their skills." (Middle manager, SOI)

"It had been agreed [that] we would protect [one of the sponsors] from [a larger sponsor, who was a competitor] because if they put a huge amount of money into an advertising campaign it could dwarf [the smaller one]. So we had to put that as part of the [large sponsor's] contract that they had limited promotion which suited them." (Senior manager, SOI)

"We are going to organisations and businesses and companies and asking them on a three-tier system. The first tier would be just to give us the platform to give the information to their employees. The second tier would be that they might give two or three days off, as in not being taken from their holidays, and third would be to give five days, five working days to the volunteers and give them back those days from their holidays." (Middle manager, SOI)

"The public were hit with different advertising campaigns. They were different in the sense that different sponsors were coming in at different times because we didn't want them competing with each other." (Middle manager, SOI)

"The six official sponsors got ownership of a specific Games programme ... they would have got dominant signage at the sports venues ... the official suppliers got sponsorship of some of the sports venues but they didn't get the ownership of the programme." (Middle manager, SOI)

"Everybody was given access [but] the premier and official sponsors were given free space, the official suppliers and friends had to pay for space." (Middle manager, SOI)
Sponsors

Volunteers

Volunteers

Volunteers

Sponsors

Volunteers

Sponsors

Sponsors

Sponsors
Sponsors

Note: SOI $=$ Special Olympics Ireland. 
The SOI also guided supportive partners by allowing autonomy regarding the delivery of their contributions while at the same time establishing binding requirements and boundaries to be respected. This way of structuring relationships with its resource providers allowed the focal organization to capitalize upon partners' commitment and specific capabilities, made them accountable in the eyes of the public for the success of the initiatives for which they were responsible, and enabled the SOI to oversee their conduct in relation to the Games and ensure that the intended event objectives were attained. For example, although the SOI allowed corporate entities a significant degree of autonomy over how their involvement with the event was going to be communicated to the public, the social venture set stringent criteria for the use of the logo of the Games and had the final say on the content of all external communication. A middle manager recalled how "we were given the scripts of loads of commercials to see if they [had] the correct terminology and references to the Games. [If a mistake was found], we would have explained the situation . . . and ask[ed] people to withdraw it." Similarly, volunteers were given discretion over how specific activities were going to be run but were also provided with blueprints to be followed and milestones to be met. The SOI positioned the relationship with its partners as mutually beneficial and emphasized that they should work together rather than disagree with each other in order to appropriate the most value from each transaction. For example, one representative of a corporate entity admitted that the SOI "made it crystal clear as to what each sponsor had to do to fit with the programme." Another remarked that "it was so much a partnership approach: they knew what we were doing and why we were doing it. We knew what they were doing, what they needed to do." However, while decentralization of responsibility to external partners was generally associated with positive outcomes, it occasionally exposed the social venture to vulnerability. This occurred in the case of two partners who, after pledging their support to the event, realized that they were unable to provide the full amount of funds and resources promised to the SOI because of capacity constraints and were forced to seek the assistance of external parties that were not directly involved with the Games in order to meet their obligations.

Taken together, these findings suggest that social ventures mobilize external parties after receiving initial indications of support by guiding those who remain invested and by negotiating with those who become critical of an event's organization. While earlier studies have recognized the need for social ventures to facilitate participation of external parties as a means to access resources, particularly specialized ones (Di Domenico et al., 2010; Peredo \& Chrisman, 2006), they have paid little attention to the mechanisms that are used to promote participation. Social ventures have been shown to foster the participation of key external parties with valuable contacts or with persons who can facilitate access to much-needed resources because of their roles in governance structures (e.g., chairmen). However, the success of a social venture's advocacy generally relies on mass participation from the referent community (Austin et al., 2006; Mair \& Marti, 2009; Peredo \& Chrisman). Our evidence extends an understanding of these functions by showing how social ventures foster mass participation by embedding themselves in the local community. We show how social ventures channel initial support by drawing attention to the presence of multiple opportunities to contribute and make a positive difference and by creating a sense of ownership of the event within the wider community through decentralization of responsibility over key activities, thereby harnessing greater participation than would have been possible through involving only a few major partners. 
A precondition for the use of guidance tactics such as the ones described above is the presence of trust between the focal organization and its external resource providers (see also Grey $\&$ Garsten, 2001). Thus, a social venture's decision to decentralize responsibility for certain activities is likely to rest upon an expectation that the decision would be reciprocated through trustworthy and appropriate actions in light of its counterparties' support of the underlying social cause and of their joint dependence (also see Villanueva et al., 2012), facilitated by their initial pledges of support to the event. Steps taken by social ventures to decentralize authority and offer greater participatory rights to their partners are also expected to enhance partners' sense of ownership of the event and willingness to contribute to its success (Wagner, 1995) and are consequently expected to reinforce their support of the initiative. Creating multiple opportunities to contribute and allowing for a certain level of flexibility is also particularly warranted with supportive resource providers who stand to gain little in return (e.g., volunteers), in order to channel and sustain support (Farmer \& Fedor, 2001). Thus, we propose the following:

Proposition 3a: Social ventures will channel the involvement of supportive external parties by drawing attention to the multiple opportunities for contribution to foster mass participation.

Proposition 3b: Social ventures will enable the engagement of supportive external parties by decentralizing the responsibility for delivering their chosen contributions so as to allow them to build upon their skills and capabilities.

Our analysis also reveals that the SOI engaged in negotiations with those individuals and organizations that threatened to withdraw their support because of disagreements in order to persuade them to renew their support of the Games. One area where disagreements often occurred pertained to the definition of the contributions expected from the corporate partners. As more partners came on board and pledged their resources, several of the initially supportive partners began to express concerns that the benefits they had expected to derive from their involvement with the Games would not be fully realized. A representative from one of the corporate entities explained, "You felt that you were more important in the beginning but as more people came on you began to feel less important." Another expressed concern that the public would not be aware "that [their] relationship with Special Olympics Ireland was unique." Our analysis suggests that the SOI overcame resistance by ensuring that the visibility afforded to external partners reflected the extent of support received. The venture granted each partner exclusive rights over events that were in line with their specific area of business expertise whenever possible and imposed strict contractual conditions on partners who were also competitors. For example, one informant explained how the social venture dealt with two competitors who had been enlisted as supporters and were expected to provide a contribution of equal worth. The SOI feared that the larger company could outspend the smaller one in advertising its contribution. Thus, while each partner received rights to organize and showcase its respective involvement at distinct events, the larger company's contract included a clause that capped its amount of advertising to ensure fairness.

One partner with whom the SOI engaged in protracted negotiations over the details of its contribution was a broadcasting agency. This entity had rebuffed SOI's guidance, citing the argument that their operations required greater autonomy than the social venture had been willing to allow them and/or how their specialized knowledge and skills put them at an advantage over the social venture. For example, in April 2003, the broadcaster needed to run 
through the venues where the various activities were going to be held in order to determine the positioning of its equipment. When the social venture sought to overrule this on safety grounds, the broadcaster resisted and, instead, required others to organize around its requirements:

Once the camera positions [were identified] there would have been fighting over that and the cable issues and health and safety issues and there would have been a lot of "if we can't get a camera there, we can't come here." (Corporate partner)

Eventually, the SOI acquiesced because it was not able to exert its influence over issues that the broadcaster viewed as falling within its area of competence.

Additionally, considerable disagreements between the social venture and the broadcaster ensued regarding how the latter's support of the event would be showcased. For example, the broadcaster contested the creation of a CD with the soundtrack of the Games that included music by its orchestra on grounds that its involvement had not been properly acknowledged. Publication of the first print run had already occurred, but the broadcasting agency insisted that the social venture rectify this in all future print runs. A similar disagreement arose over the catalogue for the opening ceremony of the Games:

We had an issue with the catalogue for the opening ceremony; we were broadcasting it for four and a half hours and the catalogue nearly went to print without us being mentioned in it. It had two ads, which everyone got which was part of the contract, but we were the broadcaster, which is major and which is different to just your recognition in two ads. ... [Communicating that the catalogue issue must be addressed] would have been very much with [the CEO of the organizing committee] that night, it got quite heavy. . . . Not being taken for granted, I suppose, that's what I found the hardest thing. (Corporate partner)

Our findings reveal that social ventures engage in negotiation tactics with external parties to propose solutions to emerging disagreements. These tactics are collaborative in nature as they seek to maximize joint outcomes through bargaining and making concessions. Thus we argue that in order to consolidate the relationships with their external partners, social ventures not only need to establish a connection between the cause and each group of partners' valued outcomes but also need to address how the collaboration would allow each party to achieve the desired outcomes. One important aspect of social ventures' efforts to consolidate relationships with external resource providers that emerged from our analysis involved balancing the need to make concessions to individual commercial partners, namely, to reinforce the initial positioning of collaboration with the cause as a win-win for both parties with the need to enable the distinctiveness of the contributions made by all the various partners in the eyes of the public.

Since social ventures tend to establish a large number of relationships with various agencies (Austin et al., 2006), they are more likely to confront a need to protect the interests of each member of their partner network from erosion than are commercial ventures, who tend to establish collaborative relationships with one or several more established resource providers and who, as such, can focus on protecting their own interests in these relationships (Katila et al., 2008). Our findings augment the evidence presented by some prior studies on social ventures (Di Domenico et al., 2010), which document their use persuasion tactics to 
pressurize and enlist initial support from key decision makers. These tactics are likely to be particularly fruitful when the success of the social cause depends upon the actions of one or few key stakeholders (i.e., policy makers) or when the social entity's objective is to garner grassroots support for the cause through initiatives that seek to influence key opinion leaders as a way to facilitate further participation. In this instance, we show that when the success of a social cause depends upon the involvement of several individual partners, consolidating the relationships with them involves engaging in discussions in order to reach an agreement over the aims and scopes of the collaboration. We also draw attention to how social ventures make concessions to those partners who possess specialized resources or skills that cannot be substituted or bypassed when it is not possible to reach an agreement through discussions and bargaining. Thus, we posit the following:

Proposition 4: Social ventures are more likely to make concessions to external parties who possess nonsubstitutable resources and skills than to those who do not possess them.

\section{Exerting Control in the Relationship With Resource Providers}

Our analysis also showed how, when resource providers had channeled their initial attraction to the cause into tangible contributions, the social venture grew more assertive in its relationships with them even as it continued to employ soft-power tactics. The social venture engaged in two tactics to exert control: leveraging the commitment of those partners who continued to be supportive so that they would scale up their contributions and coopting legitimate third parties to exert pressure on those partners who threatened to withdraw from the event so that they would return to being supportive or, at least, would not be disruptive to the event's organization. Table 4 presents examples of these two tactics.

The first type of tactic employed by the social venture involved making requests for additional contributions to many of its partners over and above what had been initially negotiated and proved to be a point of contention with a few of them. These requests were mainly directed by the focal organization to those partners who had been and continued to be most supportive of the event. This group comprised some of the corporate entities, volunteers, and staff. One area where the shortage of resources was particularly pressing was human resources. The social venture made requests for additional commitment of time to existing staff and volunteers. One senior SOI manager observed, "People were working at any time, night or day ... volunteers seemed to work beyond their hours, they'd do two or three shifts." Another informant similarly remarked, "I never worked so hard in my life. I didn't have a day off for about three weeks." The social venture also sought to attract additional volunteers by convincing their corporate partners to agree to the secondment of their staff to the event, as this method allowed the SOI to access needed human resources without incurring extra costs. One informant explained,

Each [functional area] director was asked to identify their needs in terms of head counts in the various areas and why did they think they needed those additional resources. A part of that exercise was also to identify did they know individuals who also may have the skills set that they needed that we could approach. ... We always tried to source either unpaid or secondment staff, and if we then couldn't source the staff through those two routes, we then went the direct paid route. (Middle manager, $\mathrm{SOI}$ ) 


\section{Table 4}

\section{Evidence of Tactics Used to Exert Control in the Relationship With Resource Providers}

\begin{tabular}{|c|c|c|}
\hline Categories & Representative quotations & Audience \\
\hline \multirow[t]{5}{*}{ Leverage } & $\begin{array}{l}\text { "[Most corporate and government agencies' partners gave] over and above } \\
\text { what they intended to give. And I think the more [the sponsors] felt it being } \\
\text { successful ... the more resources they put into it." (Senior manager, SOI) }\end{array}$ & Sponsors \\
\hline & $\begin{array}{l}\text { "The people in head office are in from eight in the morning until ten o'clock at } \\
\text { night, every single night of the week and at weekends as well." (Volunteer) }\end{array}$ & Volunteer \\
\hline & $\begin{array}{l}\text { "They [SOI's top management] relied too much on staff and on staff working } \\
\text { those kinds of hours. And on the volunteer commitment as well." (Middle } \\
\text { manager, SOI) }\end{array}$ & Staff \\
\hline & $\begin{array}{l}\text { "[Sponsors gave }] \text { over and above what they intended to give." (Senior manager, } \\
\text { SOI) }\end{array}$ & Sponsors \\
\hline & $\begin{array}{l}\text { "The sponsors . . felt that they had given a huge contribution and found it } \\
\text { interesting to find out they were being asked for extra." (Middle manager, } \\
\text { SOI) }\end{array}$ & Sponsors \\
\hline \multirow[t]{5}{*}{ Cooptation } & $\begin{array}{l}\text { "There was a wave of public opinion against the government in discriminating } \\
\text { against people with special needs." (Senior manager, SOI) }\end{array}$ & Government \\
\hline & $\begin{array}{l}\text { "[The support by international agencies] was an extra sort of leverage for us." } \\
\text { (Senior manager, SOI) }\end{array}$ & Government \\
\hline & $\begin{array}{l}\text { "[One of our divisions] wouldn't be able to supply all the vehicles from their } \\
\text { own fleet because they had to continue their day-to-day working, so they had } \\
\text { their own fleet but they hired in private operators." (Sponsor) }\end{array}$ & Sponsor \\
\hline & $\begin{array}{l}\text { "[SOI] felt they couldn't have one supplier responsible for everything. I think } \\
\text { they may have thought as well in the past that [we] were known for industrial } \\
\text { action. [The other supplier] alone wouldn't have been able to do it, but the } \\
\text { fact that [it] was there was a spur to us to try harder." (Sponsor) }\end{array}$ & Sponsor \\
\hline & $\begin{array}{l}\text { "All host towns would have a local bus operator in the area who would be doing } \\
\text { private hire, taking people to sports and dances." (Sponsor) }\end{array}$ & Sponsor \\
\hline
\end{tabular}

Note: $\mathrm{SOI}=$ Special Olympics Ireland.

In addition to approaching existing corporate partners with requests for additional contributions in the form of secondment of staff, the social venture sought to obtain tangible resources so as to reduce the pressures of resource acquisition on its budget. Several staff members of the SOI mentioned being asked to push external parties to escalate their commitment to the Games. One informant explained, "We became fundraisers and [were] always looking for things for free." Similarly, multiple corporate partners' representatives commented on how they felt subject to pressures to provide additional resources. A representative of an involved corporate entity stated, "We got the feeling from the Special Olympics that they were looking for handouts for this and that." Another, likewise, explained,

Our financial contribution was somewhere in the region of 7 to 8 million [up from 4 million] by the time we were finished and [in addition to providing funding], we also offered 27 people a six-month secondment to the Games, so we paid their salaries for six months and they worked with Special Olympics. (Corporate partner)

Several partners caved in to the social venture's requests because of a belief that the visibility that would be derived from participation in the Games would still allow them to achieve 
their initial objectives. A few others attempted to resist, either because they were unwilling to provide further resources or because they were unable to do so as a result of profitability concerns, but then yielded because of reputational considerations. For example, one partner was asked to pay for the printing of some promotional material over and above the contribution it had already made. When the partner refused because it did not consider this to be a reasonable request, the social venture resorted to exerting stronger pressures. One informant from the SOI who was working closely with this partner explained how it was made clear that "if they ever say no, it would affect their relationships with us." While the partner was dissatisfied with the way in which the issue was handled, it did eventually yield to SOI's requests. We found evidence of only two partners who were successful in rebuffing the requests made by the SOI as they had committed to providing only intangible resources and also had refused to formalize their relationship, which would have made their position less defensible. As such, they had the upper hand in their relationships with the SOI. One representative for one of the two corporate entities admitted, "I suppose it was more important to them [SOI] to work well with us [than otherwise] in the end."

Our analysis suggests that the demands for additional contributions described above allowed the social venture to address its resource gaps but would not have been sustainable in the long term. A few staff members and volunteers complained that too much had been expected of them and expressed reservations at the prospect of being involved in similar efforts in the future. An informant stated, "[A fellow staff member] would say that he wouldn't work for Special Olympics again." Another explained, "I wouldn't have the energy to do it again." Some corporate partners also expressed reservations at the prospect of getting involved in similar initiatives in the future out of concerns that the benefits derived did not reflect the size of their contribution in light of the large number of partners enlisted to participate in the event.

The SOI also used the tactic of coopting the support of powerful and legitimate third parties to exert pressures over those who threatened to withdraw their support. One such instance involved the emergence of severe acute respiratory syndrome (SARS) in early 2003 in some of the countries whose athletes were expected to participate in the Games. The Irish government, one of the event's earlier supporters, took on a conflicting position by passing a provision that denied athletes from SARS-affected countries permission to enter the country. The SOI sought the support of the community and other legitimate external parties in hopes that they could influence the government to reverse its decision. Its representatives reached out to the community through various media to provoke a wave of public outcry against the ban. For example, they drew attention to the unfairness of the decision, as business travelers and tourists from the affected countries were allowed to enter Ireland while athletes participating in the Games were not. One senior manager said, "It's unfair on the Special Olympics to say that you'll ban the participants in certain countries from travelling, yet then go on to let in tourists or businessmen from these areas." These comments were echoed by the president of Special Olympics International:

This ban - incredibly to us - appears to be directed not at the general populations coming from SARS-affected areas, but only toward our Special Olympics delegations coming from those areas. What a tragic irony it would be if Special Olympics athletes - all people with learning disabilities - would suffer such an indignity as this. (Timothy Shriver, as quoted in Joanilho, 2003: 1) 
Other agencies such as the World Health Organization (WHO) and several charitable organizations also criticized the government's decision on ethical grounds:

Last night the WHO's SARS spokesman, Mr. Dick Thompson, said the decision [to ban athletes from SARS-affected areas] went against the body's latest guidelines. "We understand that governments have to make their own assessments based on individual risks and resources. The decision [taken] today is not consistent with these guidelines." (Hennessey, 2003: 1)

There are many people in the disability sector today who are shocked and deeply disappointed at the decision to withdraw invites from these very special athletes. (Angela Kerins, National Disability Association, as quoted in Robinson, 2003: 10)

By rallying the support of external parties who questioned the decision both on medical and ethical grounds, the SOI not only obtained the endorsement of powerful and legitimate actors who could successfully exercise pressures on the government but also provoked a grassroots response from within the community, whose members took several initiatives in favor of the ban being overthrown, including writing letters to national newspapers and engaging in protests. Remarkably, the social venture was able to mobilize widespread support from a community that had a poor track record with the cause of intellectual disabilities.

On the whole, these findings indicate that while social ventures might initially be the more vulnerable party in the relationships with their resource providers, the progressive reciprocal embedding of partners that occurs through repeated interactions shifts the power relations in favor of the focal organization (also see Gulati \& Sytch, 2007). The social venture's attempts to escalate the contributions expected from its partners do not contradict the tenets of this reciprocal dependence, since relationships, in order to be sustainable and create shared value, should be equitable (i.e., each partner should perceive that the relationship allows them to achieve valued outcomes) but not necessarily egalitarian (i.e., the benefits received by each partner do not need to be equal to those received by others; Villanueva et al., 2012).

A social venture's exercise of soft control can occur through direct or indirect tactics depending upon the level of a partner's support of the collaborative effort and on the level of clout needed to convince a partner to comply with the venture's requests. We found that the SOI used a direct tactic with those partners who continued to be engaged in the cause and viewed the event as creating value for them. This tactic was akin to bricolage (Baker \& Nelson, 2005; Di Domenico et al., 2009) as the social venture tapped its existing ties to obtain additional resources, often in a creative and cost-effective manner, such as by seeking the secondment of staff from its corporate partners. Prior studies have argued that bricolage is a means by which newly established social ventures make do with any resource they can access out of necessity and vulnerability (i.e., satisfice). Furthermore, it is said to be an approach that is abandoned once the organization has acquired prominence in the relationship with its resource providers (Desa \& Basu, 2013). Our findings, however, show that social ventures can continue using bricolage as a means to acquire resources that they actually need (i.e., organizations can maximize) even after having established an ongoing relationship with their resource providers. This is due to the reciprocal embeddedness of the partners that facilitates a shift in power relations. In this study, the indirect tactic of cooptation (Selznick, 1949) was found to be used instead with those parties who threatened to withdraw their support to the cause. 
Cooptation of legitimate third parties to support one's agenda is a particularly useful tactic when one is dealing with more powerful actors because it helps level the playing field, particularly in situations when direct interactions have failed (Cialdini, 2001). This tactic shares some similarities with activities such as lobbying and collective action, as described by Di Domenico and colleagues (2010), in that in both cases, social ventures seek to influence a powerful stakeholder to comply with their requests through a third party, most commonly the members of the local community. The success of these activities is generally attributed to the networking efforts of the social ventures and their rapport with key members of the community. Our study instead draws attention to the use of communication that invokes commonly held values, such as equality and fairness, as a means to portray the resisting parties' arguments and exert grassroots pressures on dissenting parties. Although references to rhetorical tactics that appeal to a target audience's moral and ethical dispositions (ethos) through references to the right and appropriate thing to do can be found in the literature on the diffusion of new practices (Green, 2004; Suchman, 1995), they have received little attention in the literature on social ventures. We provide evidence on how ethos-based appeals are a powerful tool that could assist social ventures in not only facilitating external parties' initial involvement with their cause but also overcoming the resistance of powerful partners. Thus we posit the following:

Proposition 5a: Social ventures will tend to become increasingly demanding of contributions and more assertive with supportive resource providers as these relationships mature.

Proposition 5b: Social ventures will tend to deal with conflict with dissenting resource providers by coopting the support of legitimate external parties who advocate on their behalf.

\section{Discussion and Conclusion}

This study analyzed how a social venture leveraged its organization of a large event to mobilize much-needed resources for a social cause that historically had a low profile. The focus was on the actions taken by the social venture to manage its relationships with multiple partners over time as its resource mobilization gathered momentum. We have shown how, despite being highly dependent on external resources, the social venture was able to create conditions of mutual dependence and exercise agency in its relationships with resource providers through the use of tactics rooted in soft forms of power. The exercise of power was dynamic as these tactics varied in intensity depending upon the maturity of the relationship with each partner and their current level of support of the effort. Specifically, the social venture sought to engage potential partners by attracting them through values-based and interests-based discursive tactics. They also sought to consolidate and formalize this initial engagement by offering guidance and facilitating decentralization. When tensions and conflicts arose with some partners, the social venture embarked in negotiations and made concessions to those partners who possessed critical and nonsubstitutable skills. When making concessions was not feasible (e.g., during the SARS crisis), it sought the support of other legitimate entities to exert pressure on the resisting partners. It must, however, be clarified that the use of soft power was not Machiavellian in nature. Rather, it enabled social outcomes in a collaborative manner. Figure 1 captures one explanation of how social ventures can mobilize resources through engendering mutual dependence. 
Figure 1

\section{Framework on Resource Mobilization Through Mutual Dependence by Social Ventures}

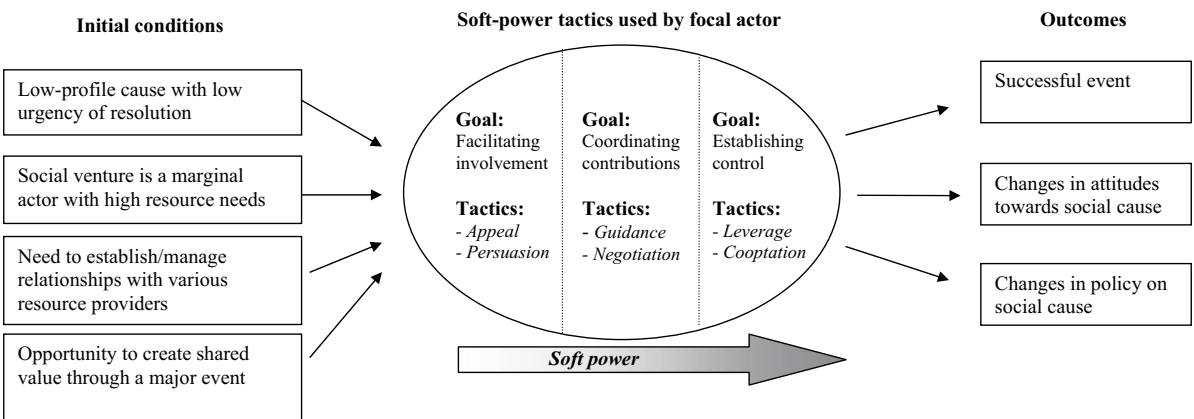

\section{Theoretical Implications}

The findings of our study have several theoretical implications. First, following some recent reviews of the social entrepreneurship literature that have urged a stronger grounding in mainstream organization theories (Nicholls, 2010; Short, Moss, \& Lumpkin, 2009), we highlight how resource dependence theory offers a particularly appropriate theoretical anchor, given its recent focus on how resource-needy actors can manage their resource disadvantages. Thus, we urge future research in the domain of social entrepreneurship to deliver upon the promise of this recent interest in the area of "mutual dependence" (e.g., Casciaro \& Piskorski, 2005; Gulati \& Sytch, 2007; Villanueva et al., 2012) and augment current understandings of how social ventures can manage their resource needs and create shared value. While we explored how social ventures might achieve this through the organization of a large-scale event, additional opportunities exist to build theory in this area, including exploring the role of alternative mechanisms (e.g., long-term partnerships), comparing the various outcomes obtainable from establishing relationships with different degrees of mutual dependence, and investigating the boundary conditions and limitations of mutual dependence.

Second, there is a need to build theory on how social ventures mobilize resources while advocating for different types of causes. Our article has begun to address this gap by demonstrating how large-scale events can serve as a catalyst for social change in the area of learning disabilities. However, it would be reasonable to assume that the choice of advocacy techniques would be affected by the intrinsic characteristics of a cause, such as its content and urgency of resolution. For example, Einstein (2012) highlights how "female-centric" causes related to topics such as children and health (e.g., curbing childhood obesity) are likely to face lesser challenges to mobilize support than non-female-centric and controversial causes (e.g., planned parenthood, gay marriage). Clearly, opportunities exist for multiple case studies that identify the similarities and differences between the approaches employed by social ventures to strike resonance with their target audience and successfully advocate for different causes. 
Third, there is merit in further exploring the role and relevance of events and communityembedded initiatives and tactics to mobilize support from prospective resource providers. Our study pointed out how establishing emotional resonance with a cause, appealing to positive emotions, and providing partners with a chance to make a difference may facilitate resource mobilization. However, there is a need for additional theory on the role, sequence, and appropriateness of other types of appeals (e.g., guilt, shame) and how they affect the willingness of an external party to contribute to a social venture's event or cause. The literature on impression management and rhetoric (e.g., Benford \& Snow, 2000; Bolino, Kacmar, Turnley, \& Gilstrap, 2008; Green, 2004) may provide insights on the use of different types of discourse. More generally, while geographic factors facilitated embeddedness to a cause in our study, future research could also empirically test the relevance of other dimensions of proximity to a cause (e.g., level of exposure to a cause, perceived relevance) and how they affect embeddedness.

Finally, we have begun to elaborate the role of soft power and soft control (Courpasson, 2000; Nye, 1990; Santos \& Eisenhardt, 2009) in helping social ventures establish and simultaneously manage relationships with multiple external parties. Barring exceptions, scholars seem to have overlooked this important aspect. Soft power emerged in our study as the key logic that facilitates mutual dependence, albeit one that might not be successful with all external parties across all situations. However, ample opportunities exist to further elaborate the types, applications, and constraints to the use of soft power in managing relationships with external parties. Such a focus on soft power promises to tease out the fine-grained dynamics of managing relationships, an area identified by Pfeffer and Salancik (2003) as needing further elaboration within resource dependence theory. Additionally, while much attention has been paid to what might be deemed less than virtuous uses of power (Pfeffer, 1992), there is merit in exploring its more virtuous uses, such as its role in creating social value.

\section{Implications for Practice and Policy}

Our study has several implications for practice and policy. First, we draw attention to how social ventures would benefit from appealing to both the values and interests of prospective partners within the venture's referent community. We also show the potential of communityembedded events to serve as catalysts for shared economic and social value creation when they offer visibility to prospective resource providers and allow for carving niches for contributions whereby resource providers can be clearly identified and linked to specific elements of the larger event. Second, and in contrast to looking at interactions with external parties either as disruptions that must be minimized or as one-time transactions, managers of social ventures would benefit from adopting a participatory style that allows for multiple ways to contribute. Third, our study highlights the benefits of using key events and crises as opportunities to implement reforms and seek greater contributions from external parties. Fourth, we identify the importance of enlisting and showcasing the early support of visible organizations. We believe that this might be an effective way of encouraging bystanders to emulate the early supporters. Finally, our framework on soft power offers actionable insights into managing relationships, especially within horizontal arrangements where the use of hard power is not possible or effective. 
In addition to its relevance to social ventures and entrepreneurial firms, our findings have practical relevance to domains in which horizontal relationships are rife and collaborative activity commonplace. Three such domains include coproduction, public-private partnerships, and constrained cooperatives. First, the coproduction literature highlights the various ways in which a variety of external parties can cocreate value for a focal organization (Ramirez, 1999). Examples include open-source technologies, such as Linux, which benefit from mass contributions by software developers who do not know each other, and reality shows, such as American Idol and Britain's Got Talent, which give voice to the community through their active calls for participation. Second, the state can play a role in social and economic as well as public-order "spaces." In Europe, public-private partnership initiatives are being promoted as an efficient and effective method of achieving public good with limited state resources. Opportunities exist for resource-needy actors to use the soft-power tactics described in our model to promote and implement their agendas. Third, constrained cooperatives may use soft-power tactics to rebalance economic relations between farmers, who strive to obtain higher prices for their produce and lower costs for their inputs, and the cooperative's management, which needs to balance gains for farmer owners against the cooperative's need to remain viable over time.

\section{Notes}

1. A 2001 survey by the Irish National Disability Authority (2002) revealed high levels of prejudice against people with learning disabilities, with only one in two people believing that these individuals should have similar access to employment as everyone else. Additionally, while the Paralympic Games receive support and contributions from the International Olympics Association, the Special Olympic Games do not.

2. Although it would have been interesting to include more information about the bidding process, this was not only beyond the scope of our study but also unfeasible for a number of reasons. First, this was a low-key process until the decision to host the Games in Ireland was taken and much of the bidding occurred behind the scenes. Thus, there were very few archival materials on this matter. Second, the real momentum and activities undertaken to organize the Games occurred only in the 2 years prior to their start date. Accordingly, we confine ourselves to presenting a detailed account of only those activities that were directly relevant to our research question.

\section{References}

Andreoni, J. 2006. Leadership giving in charitable fund-raising. Journal of Public Economic Theory, 8: 1-22.

Austin, J., Stevenson, H., \& Wei-Skillern, J. 2006. Social and commercial entrepreneurship: Same, different or both? Entrepreneurship Theory and Practice, 30: 1-22.

Baker, T., \& Nelson, R. 2005. Creating something from nothing: Resource construction through entrepreneurial bricolage. Administrative Science Quarterly, 50: 329-366.

Barringer, B., \& Harrison, J. 2000. Walking a tightrope: Creating value through interorganizational relationships. Journal of Management, 26: 367-403.

Battersby, E. 2003. Where sport is still something special. Irish Times, January 7: 11.

Belfast News Letter. 2001. Equestrian world: Equestrian briefing. October 27: 56.

Benford, R., \& Snow, D. 2000. Framing processes and social movements: An overview and assessment. Annual Review of Sociology, 26: 611-639.

Bennett, R., \& Sargeant, A. 2005. The nonprofit marketing landscape: Guest editors' introduction to a special section. Journal of Business Research, 58: 797-805.

Boland, R. 2002. The land of a thousand welcomes. Irish Times, April 16: 11.

Bolino, M., Kacmar, M., Turnley, W., \& Gilstrap, B. 2008. A multi-level review of impression management motives and behaviors. Journal of Management, 34: 1080-1109.

Casciaro, T., \& Piskorski, M. J. 2005. Power imbalance, mutual dependence, and constraint absorption: A closer look at resource dependence theory. Administrative Science Quarterly, 50: 167-199. 
Cialdini, R. 2001. Harnessing the science of persuasion. Harvard Business Review, 79(9): 72-79.

Cook, K., \& Emerson, R. 1978. Power, equity and commitment in exchange networks. American Sociological Review, 43: 721-739.

Courpasson, D. 2000. Managerial strategies of domination: Power in soft bureaucracies. Organization Studies, 21: 141-161.

Crampton, W., \& Patten, D. 2008. Social responsiveness, profitability and catastrophic events: Evidence on the corporate philanthropic response to 9/11. Journal of Business Ethics, 81: 863-873.

Creyer, E. H., \& Ross, W. T. 1997. The influence of firm behavior on purchase intention: Do consumers really care about business ethics? Journal of Consumer Marketing, 14: 421-432.

Dacin, P., Dacin, T., \& Matear, M. 2010. Social entrepreneurship: Why we don't need a new theory and how we move forward. Academy of Management Perspectives, 24: 37-57.

Davis, M. 2000. Special Olympic Games [Letter to the editor]. Irish Times, December 19: 17.

Desa, G., \& Basu, S. 2013. Optimization or bricolage? Overcoming resource constraints in global social entrepreneurship. Strategic Entrepreneurship Journal, 7: 26-49.

Di Domenico, M. L., Haugh, H., \& Tracey, P. 2010. Social bricolage: Theorizing social value creation in social enterprises. Entrepreneurship Theory and Practice, 34: 681-703.

Di Domenico, M. L., Tracey, P., \& Haugh, H. 2009. The dialectic of social exchange: Theorizing corporate-social enterprise collaboration. Organization Studies, 30: 887-907.

Duymedjian, R., \& Rüling, C.-C. 2010. Towards a foundation of bricolage in organization and management theory. Organization Studies, 31: 133-151.

Einstein, M. 2012. Charities shouldn't let corporate marketers set the agenda. The Chronicle of Philanthropy. http:// philanthropy.com/article/Don-t-Let-Corporate/131690/. Accessed December 3, 2014.

Eisenhardt, K. M. 1989. Building theory from case research. Academy of Management Review, 14: 532-550.

Eisenhardt, K. M., \& Graebner, M. E. 2007. Theory building from cases: Opportunities and challenges. Academy of Management Journal, 50: 25-32.

Farmer, S., \& Fedor, D. 2001. Changing the focus on volunteering: An investigation of volunteers' multiple contributions to a charitable organization. Journal of Management, 27: 191-211.

Glynn, M. A. 2008. Configuring the field of play: How the mega-event of the Olympics impacts civic community in host cities. Journal of Management Studies, 45: 1117-1146.

Green, S. 2004. A rhetorical theory of diffusion. Academy of Management Review, 29: 653-669.

Greenwood, R., \& Suddaby, R. 2006. Institutional entrepreneurship in mature fields: The big five accounting firms. Academy of Management Journal, 49: 27-48.

Grey, C., \& Garsten, C. 2001. Trust, control and post-bureaucracy. Organization Studies, 22: 229-250.

Gulati, R., \& Sytch, M. 2007. Dependence asymmetry and joint dependence in inter-organizational relationships: Effects of embeddedness on a manufacturer's performance in procurement relationships. Administrative Science Quarterly, 52: 32-69.

Harrision, B. 2001. Special Olympics holds record for sponsorship. Irish Times, July 19: 17.

Haugh, H. 2007. Community-led social venture creation. Entrepreneurship Theory and Practice, 31: 161-182.

Hennessey, M. 2003. WHO criticises government as athletes asked to stay away. Irish Times, May 16: 1.

Hitt, M., Ireland, D., Sirmon, D., \& Trahms, C. 2011. Strategic entrepreneurship: Creating value for individuals, organizations, and society. Academy of Management Perspective, 25: 57-75.

Irish News. 2002. Chance to be a part of the Olympic spirit. February 22: 6.

Irish Times. 2003. Fundraisers right on the money: Carl O'Brien on how backers big and small were tapped for the millions still needed. June 18: 61.

Jick, T. D. 1979. Mixing qualitative and quantitative methods: Triangulation in action. Administrative Science Quarterly, 24: 602-611.

Joanilho, M. 2003. HK official in Dublin pushes case for Special Olympics athletes. South China Morning Post, June 8: 1 .

Katila, R., Rosenberger, J., \& Eisenhardt, K. 2008. Swimming with sharks: Technology ventures, defense mechanisms and corporate relationships. Administrative Science Quarterly, 53: 295-332.

Keohane, R., \& Nye, J. 1998. Power and interdependence in the information age. Foreign Affairs, 77(5): 81-94.

Laplume, A., Sonpar, K., \& Litz, R. 2008. Stakeholder theory: Reviewing a theory that moves us. Journal of Management, 34: 1152-1189.

Lawrence, T., Malhotra, N., \& Morris, T. 2012. Episodic and systemic power in the transformation of professional service firms. Journal of Management Studies, 49: 102-143. 
Lev, B., Petrovits, C., \& Radhakrishnan, S. 2010. Is doing good good for you? How corporate charitable contributions enhance revenue growth. Strategic Management Journal, 31: 182-200.

Lounsbury, M., \& Glynn, M. A. 2001. Cultural entrepreneurship: Stories, legitimacy and the acquisition of resources. Strategic Management Journal, 22: 545-564.

Luo, X. 2005. A contingent perspective on the advantages of stores' strategic philanthropy for influencing consumer behaviour. Journal of Consumer Behaviour, 4: 390-401.

Maguire, S., Hardy, C., \& Lawrence, T. B. 2004. Institutional entrepreneurship in emerging fields: HIV/AIDS treatment advocacy. Academy of Management Journal, 47: 657-679.

Mair, J., \& Marti, I. 2009. Social entrepreneurship in and around institutional voids. Journal of Business Venturing, 24: 419-435.

Marquis, C., Glynn, M. A., \& Davis, G. F. 2007. Community isomorphism and corporate social action. Academy of Management Review, 32: 925-945.

Martens, M. L., Jennings, J. E., \& Jennings, P. D. 2007. Do the stories they tell get them the money they need? The role of entrepreneurial narratives in resource acquisition. Academy of Management Journal, 50: 1107-1132.

Martin, J., Knopoff, K., \& Beckman, C. 1998. An alternative to bureaucratic impersonality and emotional labor: Bounded emotionality at The Body Shop. Administrative Science Quarterly, 43: 429-469.

Martin, R., \& Osberg, S. 2007. Social entrepreneurship: The case for definition. Stanford Social Innovation Review, 5: 29-39.

McNamara, P., Murray, G., Grampp, C., \& Brown, P. 2003. 2003 Special Olympics World Summer Games: Managing a stakeholder network. European Case Clearing House Collection, Code 303-001-1.

Miles, M. B., \& Huberman, A. M. 1994. Qualitative data analysis: An expanded source-book. London: Sage.

Muller, A., \& Kraussl, R. 2011. Doing good deeds in times of need: A strategic perspective on corporate disaster donations. Strategic Management Journal, 32: 911-929.

Nag, R., Corley, K., \& Gioia, D. 2007. The intersection of organizational identity, knowledge, and practice: Attempting strategic change via knowledge grafting. Academy of Management Journal, 50: 821-848.

National Disability Authority. 2002. Public attitudes to disability in the Republic of Ireland. http://nda.ie/ndasitefiles/attitude.pdf. Accessed December 3, 2014.

Nicholls, A. 2010. The legitimacy of social entrepreneurship: Reflexive isomorphism in a pre-paradigmatic field. Entrepreneurship Theory and Practice, 34: 611-633.

Nye, J. S. 1990. Soft power. Foreign Policy, 80: 153-171.

Nye, J. S. 2004. Soft power: The means to success in world politics. New York: Public Affairs Press.

Office of the Tanaiste. 1996. Report of the interdepartmental group established to examine the feasibility of Ireland making a bid to host the Special Olympics World Summer Games in 2003. Dublin, Ireland: Stationery Office.

Parmigiani, A., \& River-Santos, M. 2011. Clearing a path through the forest: A meta-review of interorganizational relationships. Journal of Management, 37: 1108-1136.

Peloza, J. 2006. Using corporate social responsibility as insurance for financial performance. California Management Review, 48(2): 52-72.

Peredo, A., \& Chrisman, J. 2006. Toward a theory of community-based enterprise. Academy of Management Review, 31: 309-328.

Pfeffer, J. 1992. Understanding power in organizations. California Management Review, 34(2): 29-50.

Pfeffer, J., \& Salancik, G. 2003. The external control of organizations: A resource dependence perspective. New York: Harper \& Row.

Ramirez, R. 1999. Value co-production: Intellectual origins and implications for practice and research. Strategic Management Journal, 20: 49-65.

Robinson, V. 2003. Pressure on Martin to overturn decision. Irish News, May 17: 10.

Santos, F., \& Eisenhardt, K. 2009. Constructing markets and shaping boundaries: Entrepreneurial power in nascent fields. Academy of Management Journal, 52: 643-671.

Schrock, D., Holden, D., \& Reid, L. 2004. Creating emotional resonance: Interpersonal emotion work and motivational framing in a transgender community. Social Problems, 51: 61-81.

Selznick, P. 1949. TVA and the grass roots. Berkeley: University of California Press.

Short, J. C., Moss, T. W., \& Lumpkin, G. T. 2009. Research in social entrepreneurship: Past contributions and future opportunities. Strategic Entrepreneurship Journal, 3: 161-194.

Suchman, M. C. 1995. Managing legitimacy: Strategic and institutional approaches. Academy of Management Review, 20: 571-610. 
Tilcsik, A., \& Marquis, C. 2013. Punctuated generosity: How mega-events and natural disasters affect corporate philanthropy in U.S. communities. Administrative Science Quarterly, 58: 111-148.

Tracey, P., Philips, N., \& Haugh, H. 2005. Beyond philanthropy: Community enterprise as a basis for corporate citizenship. Journal of Business Ethics, 58: 327-344.

Van de Ven, A. H. 2007. Engaged scholarship: A guide for organizational and social research. Oxford, England: Oxford University Press.

Varadarajan, P. R., \& Menon, A. 1988. Cause-related marketing: A coalignment of marketing strategy and corporate philanthropy. Journal of Marketing, 52(3): 58-74.

Vestrum, I., \& Rasmussen, E. 2013. How community ventures mobilise resources. International Journal of Entrepreneurial Behaviour \& Research, 19: 283-302.

Villanueva, J., Van de Ven, A. H., \& Sapienza, H. J. 2012. Resource mobilization in entrepreneurial firms. Journal of Business Venturing, 27: 19-30.

Wagner, J. A. 1995. Studies of individualism-collectivism: Effects of cooperation in groups. Academy of Management Journal, 38: 152-172.

Watterson, J. 1999. Games expected to attract 30,000. Irish Times, April 1: 23.

Williams, R., \& Barrett, D. 2000. Corporate philanthropy, criminal activity, and firm reputation: Is there a link? Journal of Business Ethics, 26: 341-350.

Yin, R. K. 2003. Case study research: Design and methods. Thousand Oaks, CA: Sage.

Zott, C., \& Huy, Q. N. 2007. How entrepreneurs use symbolic management to acquire resources. Administrative Science Quarterly, 52: 70-105. 